\title{
Cystic Echinococcosis in Buffaloes from Northern Region of India: Prevalence and Molecular Characterization
}

\author{
Omer Mohi U Din Sofi, Stuti Vatsya", Rajeev Ranjan Kumar and A.K. Upadhyaya \\ Department of Veterinary Parasitology, College of Veterinary and Animal Sciences, G.B. \\ Pant University of Agriculture and Technology, Pantnagar, Uttarakhand, India \\ *Corresponding author
}

\begin{tabular}{|l|}
\hline Ke y w or d s \\
Cystic \\
echinococcosis, \\
Buffaloes, \\
Protoscolices, Cox1 \\
gene, G5 genotype
\end{tabular}

\section{A B S T R A C T}

The present investigation was undertaken to study the prevalence of cystic echinococcosis (CE) in buffaloes slaughtered at slaughter houses in parts of northern India for a period of one year from January, 2017 to December, 2017. Of the 322 animals screened, the overall prevalence rate of $12.11 \%$ of CE was observed [Udham Singh Nagar district $(\mathrm{n}=150)$ - 10\% (lungs $=53.33 \%$, liver $=26.67 \%$ and liver + lung $=20 \%)$; Nainital district $(n=172)-13.95 \%$ (lungs $=50 \%$, liver $=33.33 \%$ and liver + lung=16.66\%)]. Overall, the average prevalence of $30.76 \%, 51.28 \%$ and $17.94 \%$ was recorded in liver, lung and liver + lung, respectively with significantly $(\mathrm{P}<0.05)$ higher prevalence of cystic echinococcosis in lungs as against liver. Seasonal prevalence of CE revealed significantly $(\mathrm{P}<0.05)$ higher prevalence of $\mathrm{CE}$ in winter $(15.38 \%)$ than summer $(11.49 \%)$ and rains $(10 \%)$. Different types of cysts were recovered from various infected organs with significantly $(\mathrm{P}<0.05)$ different rates of infection [single cysts (lungs $=80 \%$, liver $=66.66 \%$ ), multiple cysts (lungs $=20 \%$, liver=33.33\%)]. The fertility rate of 39 hydatid cysts examined from total number of slaughtered buffaloes was found to be $61.53 \%$ [sterile $=25.65 \%$, calcified $=12.82 \%$ \} and significantly higher fertility rate of cysts from lungs $(65 \%)$ was observed as against liver $(58.33 \%)$ and lung + liver $(57.14 \%)$. The overall viability rate of protoscolices that were recovered from cysts of all slaughtered animals was observed to be $83.33 \%$ [lungs $(76.92 \%)$, liver $(71.42 \%)$ and liver+lungs (100\%)]. A significant $(\mathrm{P}<0.05)$ difference of the viability of protoscolices of different sizes of the cysts was also observed [ $<3 \mathrm{~cm}(0 \%), 3-6 \mathrm{~cm}(75 \%)$ and $>6 \mathrm{~cm}(93.33 \%)]$. DNA was extracted from overall 28 samples (protoscolices and laminated layer). The DNA and cox1 gene amplification fragment length of all the isolates was found to be $18 \mathrm{~kb}$ and $493 \mathrm{bp}$, respectively. The cox 1 gene sequence obtained from Udham Singh Nagar and Nainital isolate showed $100 \%$ and $99.9 \%$ identity with India, Sudan and Brazil isolates (G5 genotype), respectively which confirmed the prevalence of G5 genotype of Echinococcus granulosus in buffaloes in the study area. The nucleotide variation in the cox 1 gene sequence as compared to Brazil isolate resulted in change in the translated amino acid sequence at only 1 site for Udham Singh Nagar isolate (at position 7, Serine was replaced by Alanine) and at 2 sites for Nainital isolate (at position 98, Serine was replaced with Leucine and at position 112, Cysteine was replaced by Serine). When Udham Singh Nagar isolate was compared with the Nainital isolate, change in the amino acid sequence was observed at 2 sites (at position 98, Leucine was replaced with Serine and at position 112, Serine was replaced by Cysteine). Phylogenetic analysis of cox1 gene obtained from Udham Singh Nagar and Nainital districts of Uttarakhand revealed that the Udham Singh Nagar and Nainital isolates originated from genotype of Echinococcus granulosus in buffaloes in the study area. The nucleotide same ancestor and both had maximum relevance with G5 genotype from Brazil isolates. This is the first report of G5 genotype of CE in buffaloes from this part of northern India and thus is even more significant in understanding its zoonotic potential. 


\section{Introduction}

Cystic echinococcosis (CE) is a cestode disease which has been accounted as predominant zoonoses around the world (Deplazes et al., 2017; Petrone et al., 2015 and Thompson and Jenkins, 2014). Its place is second in helminthic disease of significance (Sangaran et al., 2014). While hydatidosis alludes to contamination with the larval stage i.e. metacestode, echinococcosis implies disease with both adult and larval contaminations (NICD, 2005). Out of the six types of Echinococcus spp. that have been perceived till date, only four (Echinococcus granulosus, E. multilocularis, E. vogeli and E. oligarthrus) have got public health significance and also both of their adult and larval stages are distinct. E. felidis (African lions) and E. shiquicus (small animals) are the two species of genus Echinococcus that have also been recognized (Moro and Schantz, 2009). CE is a neglected cyclozoonoses related with an expected 3 billion US \$ yearly misfortune to animals industry (WHO, 2017). In India, the financial misfortunes because of CE have been assessed at roughly 212 million US \$ (Singh et al., 2014). Financial misfortunes incorporate misfortunes to beef industry and are chiefly because of diminished production of milk, brought down nature of meat or fleece, impeded development, brought down fertility and condemnation of tainted organs.

Cystic echinococcosis (CE) and alveolar echinococcosis (AE) are two most essential types of echinococcosis which are of restorative and general well being significance in people (WHO, 2017). Occurrence of hydatid cysts in the intermediate hosts (sheep, goats, cows and buffaloes) in various areas leads to the condemnation of the influenced organs. The vital organs including liver, brain and lungs are most severely affected in case of CE.
Herbivorous animals are the main target for $\mathrm{CE}$ while humans may contract this disease coincidentally by food stuffs contaminated with fecal material of dogs, foxes and wolves containing the causative agent of this disease i.e. Echinococcus granulosus (Brunetti et al., 2010).

The prevalence of CE has been reported from different parts of the world viz. Iran (Ghasemian et al., 2018), Egypt (Omar et al., 2013), Pakistan (Latif et al., 2010) and Turkey (Beyhan and Umur, 2011). In India, the prevalence of CE has been reported from Tamil Nadu, India (Raman and John, 2003), Mumbai, Maharashtra (Pednekar et al., 2009), Punjab (Arif et al., 2015), North India (Singh and Dhar, 1998, Rialch et al., 2018) and Jammu (Godara et al., 2014). The Indian subcontinent provides perfect conditions for the perpetuation, spread and dispersal of $\mathrm{CE}$ in animals (Gupta et al., 2011) and human population as well (Samra et al., 2000). Customarily, contingent upon the host, the size and predilection of cysts, hydatid cysts have altogether unique rates of occurrence. Several studies have been conducted in India to evaluate the fertility and viabilty rates of protoscolices in an assortment of slaughtered animals (Tashani et al., 2002 and Elmajdoub et al., 2007).

The various species of genus Echinococcus with genotypes causing $\mathrm{CE}$ includes the $E$. granulosus sensu stricto (s.s.) (G1/G2/G3), E. granulosus sensu lato (s.l.) complex groups, E. canadensis (G6/G7/G8/G10), $E$. ortleppi (G5), $E$. equines (G4) and $E$. felidis (lion strain) (Cucher et al., 2016). At least 10 strains (G1-10) of E. granulosus s.l. have been recognized (McManus and Thompson, 2003) forming 4 major clades (G1-G3, G4, G5 and G6 to G10) (Nakao et al., 2007, 2013) all of which have variable range of hosts, ability to infect host and genetic characteristics (Eckert et al., 2001). 
Taxonomic correction of G1 to G5 as $E$. granulosus sensu stricto (G1 to G3), E. equinus (G4) and E. ortleppi (G5) has been proposed through the ongoing re-assessments of Echinococcus species (Ito et al., 2007).

Solid proof exists for species status of genotypes G6 to G10 (E. canadensis) and the lion strain (E. felidis). Natural varieties in $E$. granulosus impact its life cycle designs, pathogenesis caused in host, immunological result in host, capacity to transmit the disease and the affectability to various drugs. For instance, E. equinus, E. granulosus s.s, E. canadensis and E. ortleppi are transmitted essentially through domestic life cycles (Carmena and Cardona, 2014). This reinstates the fact that Echinococcus species identification is important as it may affect the designated developing and evaluation of prevention and control measures, diagnostic assays and therapeutics (Thompson and McManus, 2002).

In the area under study, only human reports of $\mathrm{CE}$ has been put forward from sporadic areas viz. Srinagar, Pauri Garhwal (Singh et al., 2016), Haldwani, Nainital (Shahi et al., 2015) and Dehradhun (Khare et al., 2014). In several of these reports, there has been the history of the patient's association with domestic animals like goats/sheep and dogs which is quite a practice followed by several people of some parts of northern region of India (Shahi et al., 2015) indicating the role of domestic animals in the life cycle of $E$. granulosus.

Keeping in view the above facts, the present study was undertaken with the objective to study the prevalence of cystic echinococcosis in buffaloes in some parts of northern region of India and to carry out molecular characterization of cystic echinococcosis recovered from buffaloes.

\section{Materials and Methods}

\section{Prevalence study}

The present study was conducted in the Department of Veterinary Parasitology, College of Veterinary and Animal Sciences., Govind Ballabh Pant University of Agriculture and Technology, Pantnagar and in and around two districts of (U.S. Nagar and Nainital) of northern region of India. The prevalence of cystic echinococcosis was determined in buffaloes in northern region of India for a period of 12 months (January, 2017- December, 2017) by making regular visits to the slaughter houses.

\section{Collection of cysts}

Cysts were collected from buffaloes from the various slaughter houses of Udhamsingh Nagar and Nainital districts (Fig. 1). All the organs and tissues were examined for the presence of the cysts. The cysts were placed in sterile saline solution and transported to laboratory in ice box.

\section{Organ wise distribution}

The collected cysts were counted organ wise from which they were isolated in order to assess the frequency of $\mathrm{CE}$ in different organs. The different organs were also examined for the type (single/multiple), size, fertility (fertile/sterile/calcified) and viability of the cysts (live/dead).

\section{Sizes of cysts}

The cysts collected from various organs were measured individually using scale in centimetres and were categorized in different groups $(<3 \mathrm{~cm}, 3-6 \mathrm{~cm}$ and $>6 \mathrm{~cm})$ as per the criteria described by Dalimi et al., (2002). The different sizes of the cysts were also correlated for fertility (fertile/sterile/calcified) and viability (live/dead). 


\section{Fertility of cysts}

Cyst contents were aspirated aseptically and also the germinal layer of the cysts was isolated by scraping the inner layer of the cysts. The cyst fluid and the germinal layer were examined under light microscope for the presence of protoscolices. The cysts with no protoscolices were considered infertile while as the cysts with protoscolices were considered fertile. The calcified or suppurative cysts were also considered infertile. Protoscolices were collected from individual fertile cysts, whereas germinal layer was collected from both fertile and infertile cysts under aseptic conditions. The collected material was washed three times with phosphate buffer saline [PBS (pH7.4)] by centrifugation and then stored in $70 \%$ ethanol for further use.

\section{Statistical analysis}

The percent prevalence of $\mathrm{CE}$ and data were analyzed by analysis of variance (ANOVA) (Jones, 1994). A computer program (SPSS 11.5 for windows) and Primer Minitab software was used for data analysis. Student's t-test and Chi-square test were used for the analytic assessment. The results were considered to be significant when the p-value obtained was less than 0.05 .

Following formula was used to calculate the prevalence of parasites;

Prevalence $(\mathrm{P})=$

$\frac{\text { Total number } \text { of hosts infected }}{\text { Total number } \text { of hosts examined }} \times 100$

\section{Molecular characterization}

\section{Processing of cyst elements}

Cyst contents already preserved in $70 \%$ ethanol were washed three times with PBS
(pH 7.4) by centrifugation at $447 \mathrm{x}$ g for 15 minutes. The pellet obtained was used for DNA extraction.

\section{DNA extraction}

Total genomic DNA was isolated from laminated membrane/protoscolices and hydatid fluid (for purification of DNA from any existed protoscolices suspended in hydatid fluid of fertile cysts). The DNA extraction was carried out using Uniflex ${ }^{\mathrm{TM}}$ DNA isolation kit [Bangalore Genei ${ }^{\mathrm{TM}}$ (India) Private Ltd., Bangalore] as per the protocol described by Zugin and Hartley (1985). The method included the removal of cellular proteins from the sample by adding salt (phenol: chloroform 1:1) that resulted into biphasic solution with upper aqueous phase (nucleic acids) and lower organic phase (proteins). DNA was recovered from aqueous phase by precipitation with $70 \%$ ethanol followed by centrifugation to make DNA pellets to be suspended in buffer and stored at $-20^{\circ} \mathrm{c}$ till further use.

\section{PCR assay}

Mitochondrial gene was amplified using specific primers for cytochrome $\mathrm{C}$ oxidase 1 (coxl) (Shahzad et al., 2014) (Table 1). All PCR amplification reactions, including negative control samples were carried out in a final volume of $25 \mu \mathrm{l}$ with $12.5 \mu \mathrm{l}$ of commercially available PCR master mix (GeNei ${ }^{\mathrm{TM}}$ PCR-Master Mix-2X) [Bangalore Genei $^{\mathrm{TM}}$ (India) Private Ltd., Bangalore].

\section{Forward primer}

To the available lyophilized primer $(324.9 \mu \mathrm{g})$, $440 \mu 1$ sterile water was added to make it $100 \mu \mathrm{M} / \mathrm{L}$ as per manufacturer's instructions. Twenty microliter of it was taken and diluted in $80 \mu \mathrm{l}$ of sterile water to make $20 \mu \mathrm{M} / \mathrm{L}$ or $20 \mathrm{pM} / \mu \mathrm{l}$ as working solution. 


\section{Reverse primer}

To the available lyophilized primer (374.6 $\mu \mathrm{g})$, $502 \mu 1$ sterile water was added to make it $100 \mu \mathrm{M} / \mathrm{L}$ as per manufacturer's instructions. Twenty microliter of it was diluted in $80 \mu 1$ of sterile water to make $20 \mu \mathrm{M} / \mathrm{L}$ or $20 \mathrm{pM} / \mu \mathrm{l}$ working solution.

The final reaction mixture was prepared as per the protocol of Shahzad et al., (2014). Briefly, the master mix was thawed and mixed gently. $12.5 \mu 1$ of the master mix was taken into PCR tube to which $5 \mu$ DNA lysate, $1 \mu \mathrm{l}$ each forward and reverse primer and $5.5 \mu \mathrm{l}$ sterile water was added to make the final reaction volume of $25 \mu \mathrm{l}$. The PCR program was carried out in temperature gradient thermocycler as per the protocol described by Shahzad et al., (2014). Initial denaturation at $94^{\circ} \mathrm{C}$ for 30 seconds followed by 40 cycles of each denaturation at $94^{\circ} \mathrm{C}$ and annealing at $57^{\circ} \mathrm{C}$ for 60 seconds. Amplification was done at $72^{\circ} \mathrm{C}$ for 40 seconds followed by final extension at $72^{\circ} \mathrm{C}$ for 5 minutes. PCR product was analyzed using $1.5 \%$ agarose gel. Before genotyping, the PCR product was subjected to purification as per the protocol described by Sambrook et al., (1989).

\section{Nucleotide and amino acid variability of cox1 gene}

The sequenced partial coxl gene from Udham Singh Nagar and Nainital district isolates were compared and analysed with that of already published gene sequence available in the Gene Bank. After alignment of this gene, its nucleotide variability and amino acid variability were studied.

\section{Phylogenetic analysis}

The nucleotide sequences were compared and phylogenetic analysis was done using sequence data available in Gene Bank and the sequence data obtained from the present study. The sequence data was aligned using the software Mega 7 with Clustal $W$ multiple sequence alignment. Percent similarity/percent divergence and phylogenetic tree was obtained by using BioEdit programme available in Mega 7 software.

\section{Results and Discussion}

Overall prevalence and organ wise distribution of cystic echinococcosis

Of a total of 322 buffaloes screened, an overall prevalence rate of $12.11 \%$ of CE was observed (Table 2). Overall 172 buffaloes slaughtered at slaughter houses in district Nainital were screened with a prevalence rate of $13.95 \%$. From Udham Singh Nagar district, 150 slaughtered animals were examined with a prevalence rate of $10 \%$. Overall, the average prevalence of $30.76 \%, 51.28 \%$ and $17.94 \%$ was recorded in liver, lung and liver +lung, respectively. The lungs had significantly $(\mathrm{P}<0.05)$ higher proportions of prevalence of cystic echinococcosis rather than liver. In Nainital district, liver of 8 animals, 12 lungs and 4 both liver and lungs were observed to be harbouring hydatid cyst with a prevalence rate of $33.33 \%, 50 \%$ and $16.66 \%$, respectively. In Udham Singh Nagar district, the prevalence of $\mathrm{CE}$ was found to be $26.67 \%, 53.33 \%$ and $20 \%$ in liver, lungs and both liver and lungs, respectively. A significant association between hydatidosis and organ wise location of hydatid cysts $(\mathrm{P}<0.05)$ was observed. The proportional prevalence of hydatidosis was found to be homogenous in different districts. Organ wise, the $\%$ prevalence of $\mathrm{CE}$ was significant $(\mathrm{P}<0.05)$.

In the present study, the prevalence of CE can be correlated with the places from where these buffaloes were brought to the slaughter 
houses which may have been frequented by several stray dogs. Wide variations have been recorded by several workers across India on prevalence of hydatidosis (Ghourai and Sahai, 1989; Irshadullah et al., 1989).The observation made in the present study can be correlated with Nadery et al., (2011) and Pour et al., (2012), who reported higher rate of infection in lungs in comparison to liver. Nadery et al., (2011) determined higher rate of infection in lungs (60\%) followed by liver (32\%), spleen (4\%), kidney (2\%), heart $(0.9 \%)$ and brain $(0.1 \%)$ (Table 3$)$.

\section{Seasonal prevalence of hydatidosis}

Data revealed significant seasonal patterns for infection in buffaloes $(\mathrm{P}<0.05)$ and highest prevalence values were observed during winter $(15.38 \%)$ then summer (11.49\%) followed by the rains (10\%) (Table 4). This is contrary to the findings of Arif et al., (2015) who found that infection rate was low during winter $(24.51 \%)$ as compared to spring (30\%). However, the findings of present study are in agreement with that of (Mohamadin and Abdelgadir, 2011) who also reported that the prevalence rate of $\mathrm{CE}$ was higher in winter as compared to other seasons.

Moreover, Jithendran et al., (1996) observed a high rate of $\mathrm{CE}$ in sheep $(28.3 \%)$ and goat $(19.45 \%)$, respectively in winter. However, this disease can occur in any season. One of the reasons for a higher number of infections recorded during winter may be attributed to the fact that in winter, there was an influx of buffaloes for slaughter in comparison to other seasons.

Only in some slaughter houses in the present study, slaughtering of buffaloes was done under the supervision of veterinarians. One potential purpose behind the varied rates of infection in the animals slaughtered during the study could be attributed to the changes in ecological factors. In addition, these variations could be related to the diverse strains of E. granulosus (McManus, 2010).

\section{Infection rates of organs}

Out of 20 infected lungs, 16 had single cyst (80\%) and 04 multiple cysts $(20 \%)$. From 12 infected livers, 08 were found to be harbouring single form of cysts $(66.66 \%)$ and 04 had multiple cysts (33.33) (Table 5; Figures 2 and 3). The reason for harbouring of hydatid cyst in these organs can be related to factors such as physiological and anatomical characteristics of organ, host and strain of parasite (Polat and Atamanalp, 2009). Statistical analysis between the infected organs revealed a significant difference in infection rates of different organs $(\mathrm{P}<0.05)$. In the present investigation, the lungs of buffaloes were observed to be more usually tainted with hydatid cysts as compared to other organs.

The fertility rate of hydatid cysts from slaughtered buffaloes was found to be $61.53 \%$. A total of $25.65 \%$ of the cysts were found to be sterile and $12.82 \%$ cysts were calcified. It was observed that there was a consequential difference in fertility rates of cysts recuperated from lungs and livers of slaughtered animals $(\mathrm{P}<0.05)$. In terms of the fertility rate for hydatid cysts from each study area, it was observed that in pulmonary cysts, it was $65 \%$, which was higher than that for liver $(58.33 \%)$ and commixed organs i.e., liver and lung $(57.14 \%)$. However, most of the calcified cysts were found in liver (16.66\%) followed by lungs (10\%) and commixed organs i.e. liver and lungs $(14.28 \%)$. The cysts recovered from the lungs of slaughtered buffaloes $(65 \%)$ were found to be more fertile as compared to other organs. The statistical difference was found to be significant $(\mathrm{P}<0.05)$ for the fertile cysts that were recovered from organs of slaughtered 
buffaloes. The viability of protoscolices in fertile cysts was $76.92 \%$ in lungs, $100 \%$ in liver+lungs as compared to cysts recovered from liver which was $71.42 \%$ (Table 6). The prevalence of highly fertile cysts as encountered in present study has got public health significance.

\section{Viability of hydatid cysts}

In the present study, the viability rate of protoscolices that were recuperated from all slaughtered animals was observed to be $83.33 \%$. In terms of the different cyst size of slaughtered animals, the viability rate of protoscolices was $0 \%, 75 \%$ and $93.33 \%$ for cyst size $<3 \mathrm{~cm}, 3-6 \mathrm{~cm}$ and $>6 \mathrm{~cm}$, respectively (Table 8; Figures 4). A significant statistical distinction between the viability rate of protoscolices recuperated as different sizes of cysts $(\mathrm{P}<0.05)$ was observed. Information acquired on the fertility and viability of hydatid cysts in animals plays a significant role in giving sound designators of the centrality of every domesticated animals as a conceivable source of disease to final hosts, particularly canines (Elmajdoub et al., 2007). Customarily, contingent upon the host, the size and predilection of cysts, hydatid cysts have altogether unique rates of occurrence. In such manner, vast number of studies has been directed in India to evaluate the fertility and viabilty rates of protoscolices in an assortment of slaughtered animals (Tashani et al., 2002 and Elmajdoub et al., 2007).

\section{Molecular characterization}

\section{Electrophoretic analysis of DNA and cox1 gene of Echinococcus granulosus}

DNA was extracted from samples isolated from both Udham Singh Nagar and Nainital districts of northern part of India. The DNA length of all the isolates was found to be $18 \mathrm{~kb}$ (Figure 5) and the amplification of coxl gene fragment from DNA of E. granulosus was of 493bp (Figure 6).

Cystic echinococcosis is a crucial zoonotic disease that constitutes a prime public health risk in many countries throughout the world and India in particular. Buffaloes have been found to have the highest prevalence of hydatid cysts. This is most possibly due to the older age at which the animals were slaughtered (Latif et al., 2010). In order to develop preventive and control strategies for echinococcosis, a better knowledge of transmission cycle of E. granulosus complex is the need of hour. From the various intermediate hosts, various intraspecific variants of E. granulosus from different parts of the world have been isolated by molecular characterization of various isolates (Thompson, 2008).

\section{Nucleotide sequencing of cox1gene of Echinococcus granulosus}

The coxlgene sequences received were compared with the available sequences of cox1 gene in the GeneBank using BLAST analysis available in the NCBI website (www.ncbi.nlm.nih.gov). The coxl gene sequence obtained from Udham Singh Nagar isolate showed $100 \%$ identity with India, Sudan and Brazil isolates (G5 genotype). Nainital isolate exhibited $99.9 \%$ identity with India, Sudan and Brazil isolates (G5 genotype). On the basis of this analysis, it can be concluded that there is prevalence of G5 genotype of E. granulosus in buffaloes in the study area.

For genetic variability analysis, the sequences of both the isolates were aligned with the sequence from eight field isolates using Clustal $W$ programme available in Mega 7 computer software. The changes in the gene squences were thus identified. The nucleotide sequences of both the isolates of coxl gene of 
present study and other strain sequences were translated to amino acid sequences for comparison. The amino acid sequences were translated using Mega 7 computer software.

In Udham Singh Nagar isolate (Accession number MH428013), the nucleotide variation in the coxl gene sequence as compared to Brazil (Accession number KT337323.1) isolate resulted in change in the translated amino acid sequence at only 1 site. This change was in correspondence with the change in nucleotide sequence. At position 7, Serine was replaced by Alanine. In Nainital isolate (Accesion number MH428014), the nucleotide variation in the coxl gene sequence as compared to Brazil (Accession number KT337323.1) isolate resulted in change in the translated amino acid sequence at 2 sites. These changes were in correspondence with the change in nucleotide sequence. At position 98, Serine was replaced with Leucine and at position 112, Cysteine was replaced by Serine. When Udham Singh Nagar isolate was compared with the Nainital isolate, change in the amino acid sequence was observed at 2 sites also. At position 98, Leucine was replaced with Serine and at position 112, Serine was replaced by Cysteine. The genotypes are also important regarding the host specificity and life cycle of the E. granulosus (Bowles and McManus, 1993 and Dinkel et al., 2004). In the current study, a mitochondrial marker (coxl) was used for phylogenetic studies and population differentiation because of its relatively rapid rate of evolution, importance in differentiation and discrimination of closely related genotypes. It is maternally inherited and does not undergo any recombination (McManus and Thompson, 2003; Ahmadi and Dalimi, 2006; Vural et al., 2008; Amin-Pour et al., 2011 and Sharifiyazdi et al., 2011).

Recently, Balbinotti et al., 2012 reported G5 genotype from 277 isolates collected from lung, liver and kidney of cattle which have
$100 \%$ identity with the isolates of Udham Singh Nagar and Nainital in the present study. In India, Pednekar et al., (2009) carried out the molecular characterization of isolates of Echinococcus in animals slaughtered in Mumbai (Maharashtra). Mitochondrial cytochrome c oxidase -1 (coxl) gene was amplified and sequenced. Based on the phylogenetic analysis, buffalo strain (G3) was found to be predominant followed by cattle strain (G5), sheep strain (G1) and then Tasmanian sheep strain (G2). This study is in partial agreement with the present study in which G5 genotype was found to be present in buffaloes in Uttarakhand.

Sharma et al., (2013) examined 32 patients infected with $\mathrm{CE}$ in North India. Mitochondrial cytochrome-c oxidase subunit1 (coxl) gene was amplified and sequenced for molecular identification of the isolates. From all the isolates, G3 genotype was isolated from Punjab, Haryana, Himachal Pradesh, Jammu and Kashmir and G5 genotypes was isolated from the patients of our study area. This study fully supports the zoonotic importance of G5 genotype that was also isolated during present study from buffaloes.

\section{Phylogenetic analysis of $\operatorname{cox} 1$ gene}

The coxl gene sequences of both isolates (Udham Singh Nagar and Nainital) in this study were subjected to phylogenetic analysis with 8 GeneBank sequences. The transformative history was induced utilizing the neighbor-joining method (Saitou and Nei, 1987). The ideal tree with the aggregate of branch length $=8.37919662$ is displayed. Evolutionary study was directed in MEGA7 (Kumar et al., 2016). The phylogenetic tree revealed that the Udham Singh Nagar and Nainital isolates originated from same ancestor and both had maximum relevance with G5 genotype from Brazil isolates (Accession number KT337323.1) (Fig. 7). 
Estimation of evolutionary divergence and percent identity

Analysis of evolutionary divergence and percent identity was conducted using the maximum composite likelihood model (Tamura et al., 2004). The analysis involved 10 nucleotide sequences including two sequences of present study and eight published sequences of coxl gene. There were a total of 341 positions in the final dataset. Evolutionary analyses were conducted in MEGA7 (Kumar et al., 2016). Udham Singh Nagar isolate showed $100 \%$ identity with India, Sudan and Brazil isolates (G5 genotype). Nainital isolate exhibited 99.9\% identity with India, Sudan and Brazil isolates (G5 genotype) (Fig. 8). This is the first report of G5 genotype of CE in buffaloes from this part of India and thus is even more significant in understanding its zoonotic potential.

Prior examinations about the strains of E.granulosus in animals of Eastern India exhibited the prevalence of four genotypes G1, G2, G3 and G5 (Bhattacharya et al.,
2008). G1, G2 and G3 genotypes have been secluded from domesticated animals of West Bengal (Craig et al., 2007). Four unique genotypes i.e. G1, G2, G3 and G5 genotype have been secluded from food producing animals in Maharashtra and bordering region of Western India (Pednekar et al., 2009) while as from North India, G1 and G3 genotypes have been found in domesticated animals (Singh et al., 2012). G1 and G3 genotypes have zoonotic potential and are additionally prevalent genotypes affecting people in India. G3 genotype has been isolated from Punjab, Haryana, Himachal Pradesh, Jammu and Kashmir and G5 genotypes have been isolated from the patients of the study area (Sharma $e t$ al., 2013).

The rural communities have a practice of rearing domestic animals like sheep, goat, cattle and buffaloes and dogs together. Sometimes people also go for home slaughter/open slaughter of animals on specific occasions and the offal is fed to dogs in the vicinity.

Table.1 Primers specific to cox 1 gene

\begin{tabular}{|l|l|l|}
\hline Name & Type & \multicolumn{1}{c|}{ Sequence } \\
\hline $\begin{array}{l}\text { Primer } \\
(\cos 1)\end{array}$ & Forward & 5-TTT TTT GGG CAT CCT GAG GTT TAT-3 \\
\hline
\end{tabular}

Table.2 Overall prevalence and organ wise distribution of hydatidosis in buffaloes from January, 2017 to December, 2017

\begin{tabular}{|c|c|c|c|c|c|c|c|c|c|}
\hline \multirow[t]{3}{*}{ Districts } & \multirow{3}{*}{$\begin{array}{l}\text { Animals } \\
\text { examined }\end{array}$} & \multirow{3}{*}{$\begin{array}{l}\text { Animals } \\
\text { Infected }\end{array}$} & \multirow{3}{*}{$\begin{array}{l}\text { Prevalence } \\
(\%)\end{array}$} & \multicolumn{6}{|c|}{ Infected Organs } \\
\hline & & & & \multicolumn{2}{|c|}{ Liver } & \multicolumn{2}{|c|}{ Lungs } & \multicolumn{2}{|c|}{ Liver +Lung } \\
\hline & & & & No. & $\%$ & No. & $\%$ & No. & $\%$ \\
\hline Nanital & 172 & 24 & $13.95 *$ & 08 & 33.33 & 12 & $50 *$ & 04 & 16.66 \\
\hline $\begin{array}{l}\text { Udham Singh } \\
\text { Nagar }\end{array}$ & 150 & 15 & $10^{*}$ & 04 & 26.67 & 08 & $53.33^{*}$ & 03 & 20 \\
\hline Overall & 322 & 39 & 12.11 & 12 & 30.76 & 20 & 51.28 & 07 & 17.94 \\
\hline
\end{tabular}


Table.3 Month wise prevalence of hydatidosis in buffaloes

\begin{tabular}{|l|c|l|l|}
\hline \multirow{2}{*}{ Month } & \multicolumn{2}{|c|}{ Buffalo } & \\
\cline { 2 - 4 } & Examined & Infected & \% \\
\hline January, 2017 & 45 & 04 & 8.88 \\
\hline February & 40 & 04 & 10 \\
\hline March & 22 & 02 & 9.09 \\
\hline April & 20 & $03^{* *}$ & 15 \\
\hline May & 15 & $03^{*}$ & 20 \\
\hline June & 25 & 02 & 08 \\
\hline July & 15 & 01 & 6.66 \\
\hline August & 20 & $04^{*}$ & 20 \\
\hline September & 30 & $06^{*}$ & 20 \\
\hline October & 20 & 02 & 10 \\
\hline November & 40 & 04 & 10 \\
\hline December, 2017 & 30 & $04^{* *}$ & 13.33 \\
\hline Overall & $\mathbf{3 2 2}$ & $\mathbf{3 9}$ & $\mathbf{1 2 . 1 1}$ \\
\hline *(P<0.01) $* *(\mathbf{P}<\mathbf{0 . 0 5})$ & & & \\
\hline
\end{tabular}

Table.4 Seasonal prevalence of hydatidosis in buffaloes

\begin{tabular}{|c|c|c|c|}
\hline \multirow{2}{*}{ Season } & \multicolumn{3}{|c|}{ Buffalo } \\
\cline { 2 - 4 } & Examined & Infected & \% Prevalence \\
\hline Winter & 95 & $16^{*}$ & 15.38 \\
\hline Summer & 112 & 10 & 11.49 \\
\hline Rains & 115 & $13^{* *}$ & 10 \\
\hline Overall & $\mathbf{3 2 2}$ & $\mathbf{3 9}$ & $\mathbf{1 2 . 1 1}$ \\
\hline$*(\mathbf{P}<\mathbf{0 . 0 1}) * *(\mathbf{P}<\mathbf{0 . 0 5})$ & & & \\
\hline
\end{tabular}

Table.5 Frequency of the forms of hydatid cysts from different organs

\begin{tabular}{|c|c|c|c|c|c|c|}
\hline \multirow[t]{3}{*}{ Animal } & \multirow{3}{*}{$\begin{array}{l}\text { Number } \\
\text { Examined }\end{array}$} & \multirow{3}{*}{$\begin{array}{l}\text { Number } \\
\text { Positive }\end{array}$} & \multicolumn{4}{|c|}{ Forms of Cyst } \\
\hline & & & \multicolumn{2}{|c|}{ Single } & \multicolumn{2}{|c|}{ Multiple } \\
\hline & & & No. & $\%$ & No. & $\%$ \\
\hline \multirow[t]{3}{*}{ Buffalo } & Lungs & 20 & $16^{*}$ & 80 & 04 & 20 \\
\hline & Liver & 12 & 08 & 66.66 & 04 & $\begin{array}{c}33.3 \\
3\end{array}$ \\
\hline & Liver+ Lung & 07 & 05 & 71.42 & $02 *$ & 40 \\
\hline \multicolumn{2}{|c|}{ Overall } & 39 & 29 & 74.35 & 10 & $\begin{array}{c}25.6 \\
5\end{array}$ \\
\hline$*(\mathbf{P}<\mathbf{0 . 0 5}$ & & & & & & \\
\hline
\end{tabular}


Table.6 Fertility rate of hydatid cysts and viability of protoscolices recovered from different organs

\begin{tabular}{|c|c|c|c|c|c|c|c|c|c|c|}
\hline \multirow{3}{*}{ Animal } & \multirow{3}{*}{$\begin{array}{c}\text { Infected } \\
\text { Organs } \\
\text { Examined }\end{array}$} & \multirow{3}{*}{$\begin{array}{l}\text { No. of } \\
\text { Infected } \\
\text { Organs }\end{array}$} & \multicolumn{6}{|c|}{ Type of Cyst } & \multirow{2}{*}{\multicolumn{2}{|c|}{$\begin{array}{c}\text { Viability of } \\
\text { Protoscolicies } \\
\text { in Fertile Cysts }\end{array}$}} \\
\hline & & & \multicolumn{2}{|c|}{ Sterile } & \multicolumn{2}{|c|}{$\begin{array}{l}\text { Suppurative or } \\
\text { Calcified }\end{array}$} & \multicolumn{2}{|c|}{ Fertile } & & \\
\hline & & & No. & $\%$ & No. & $\%$ & No. & $\%$ & No. & $\%$ \\
\hline \multirow[t]{3}{*}{ Buffalo } & Lungs & 20 & 05 & 25 & 02 & 10 & $13^{* *}$ & 65 & 10 & 76.92 \\
\hline & Liver & 12 & 03 & 25 & 02 & 16.66 & $07 * *$ & 58.33 & 05 & 71.42 \\
\hline & $\begin{array}{l}\text { Liver+ } \\
\text { Lung }\end{array}$ & 07 & 02 & 28.57 & 01 & 14.28 & $04 *$ & 57.14 & 05 & 100 \\
\hline \multicolumn{2}{|c|}{ Overall } & 39 & 10 & 25.65 & 05 & 12.82 & 24 & 61.53 & 20 & 83.33 \\
\hline \multicolumn{11}{|c|}{$\begin{array}{l}* \mathrm{P}<0.05 ; \text { T }- \text { Value }=5.07 \mathrm{P}-\text { Value }=0.015 \\
* * \mathrm{P}<0.01 ; \text { T }- \text { Value }=6.99 \mathrm{P}-\text { Value }=0.006\end{array}$} \\
\hline
\end{tabular}

Table.7 Fertility rate of different sizes of the hydatid cysts

\begin{tabular}{|c|c|c|c|c|c|c|c|c|}
\hline \multirow{3}{*}{$\begin{array}{l}\text { Animal } \\
\text { Species }\end{array}$} & \multirow{3}{*}{$\begin{array}{l}\text { Cyst Size } \\
\text { (Cm) }\end{array}$} & \multirow{3}{*}{$\begin{array}{l}\text { No. of } \\
\text { Cysts }\end{array}$} & \multicolumn{6}{|c|}{ Type of Cyst } \\
\hline & & & \multicolumn{2}{|c|}{ Sterile } & \multicolumn{2}{|c|}{$\begin{array}{l}\text { Suppurative or } \\
\text { Calcified }\end{array}$} & \multicolumn{2}{|c|}{ Fertile } \\
\hline & & & No. & $\%$ & No. & $\%$ & No. & $\%$ \\
\hline \multirow{3}{*}{ Buffalo } & $<3$ & 10 & $06^{*}$ & 60 & 03 & 30 & 01 & 10 \\
\hline & $3-6$ & 12 & 03 & 25 & 01 & 8.33 & $08 * *$ & 66.66 \\
\hline & $>6$ & 17 & 01 & 5.88 & 01 & 5.88 & $15^{* *}$ & 88.23 \\
\hline \multicolumn{2}{|c|}{ Total } & 39 & 10 & 25.65 & 05 & 12.82 & 24 & 61.53 \\
\hline \multicolumn{9}{|c|}{$\begin{array}{l}* \mathrm{P}<0.05 ; \mathrm{T}-\text { Value }=5.07, \mathrm{P}-\text { Value }=0.015 \\
* * \mathrm{P}<0.01 ; \mathrm{T}-\text { Value }=6.99, \mathrm{P}-\text { Value }=0.006\end{array}$} \\
\hline
\end{tabular}

Table.8 Viability of different sizes of the fertile hydatid cysts

\begin{tabular}{|l|c|c|c|c|c|c|}
\hline \multirow{2}{*}{$\begin{array}{c}\text { Animal } \\
\text { Species }\end{array}$} & $\begin{array}{c}\text { Cyst Size } \\
(\mathbf{C m})\end{array}$ & $\begin{array}{c}\text { No. of } \\
\text { Cysts }\end{array}$ & \multicolumn{2}{|c|}{ Fertile Cysts } & \multicolumn{2}{|c|}{$\begin{array}{c}\text { Viability of } \\
\text { Protoscolices }\end{array}$} \\
\cline { 3 - 7 } & & & No. & $\%$ & No. & $\%$ \\
\hline \multirow{2}{*}{ Buffalo } & $<3$ & 10 & 01 & 10 & 0 & 0 \\
\cline { 2 - 7 } & $3-6$ & 12 & 08 & 66.66 & 06 & $75 \%$ \\
\hline & $>6$ & 17 & 15 & 88.23 & $14 *$ & 93.33 \\
\hline & Total & $\mathbf{3 9}$ & $\mathbf{2 4}$ & $\mathbf{6 1 . 5 3}$ & $\mathbf{2 0}$ & $\mathbf{8 3 . 3 3}$ \\
\hline \multirow{2}{*}{ *(P<0.05) } & & & & & \\
\hline
\end{tabular}


Fig.1 Maps showing collection sites of hydatid cysts in Udham Singh Nagar and Nainital districts
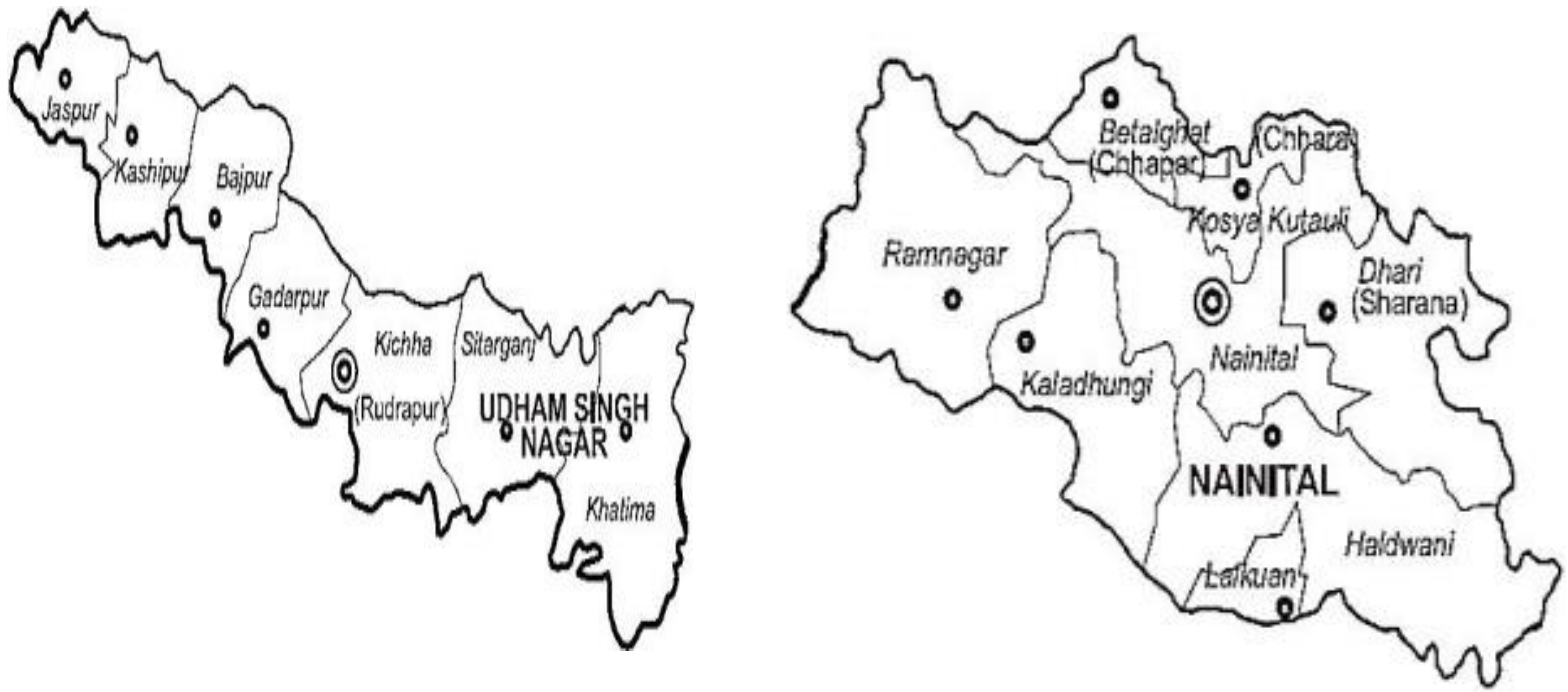

Fig.2 Photograph showing single cysts collected from lungs (a) and liver (b) of buffaloes

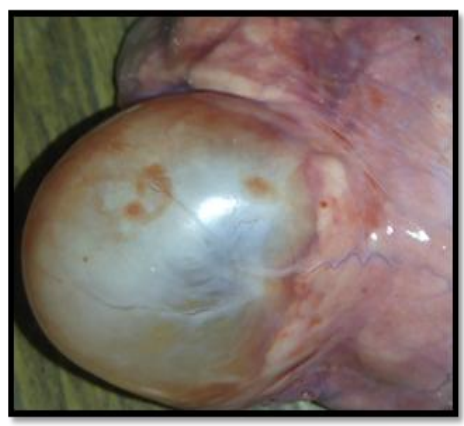

(a)

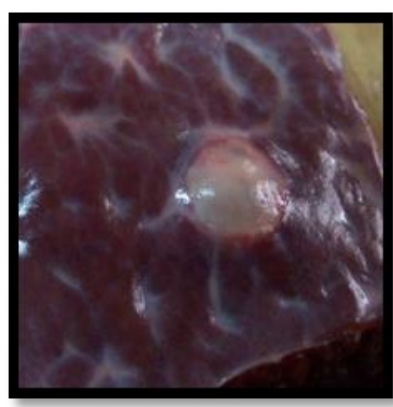

(b)

$\mathrm{NE}=$ No. of infected organs examined $\mathrm{NP}=$ No. of infected organs

Fig.3 Photograph showing multiple cysts collected from lungs (a) and liver (b) of buffaloes Fertility rate of hydatid cysts

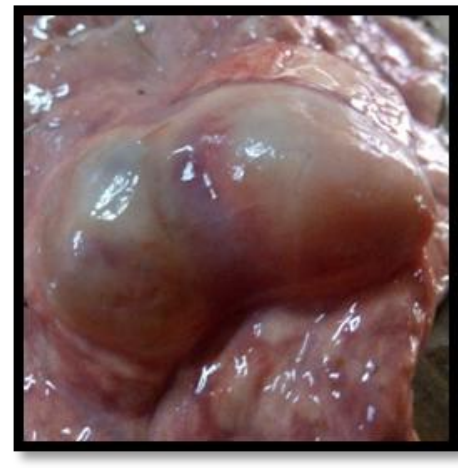

(a)

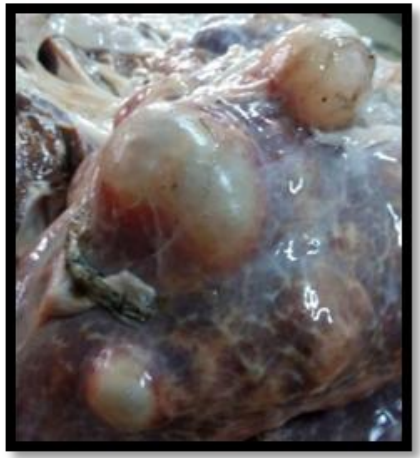

(b) 
Fig.4 Photographs showing protoscolices stained with $0.1 \%$ aqueous eosin

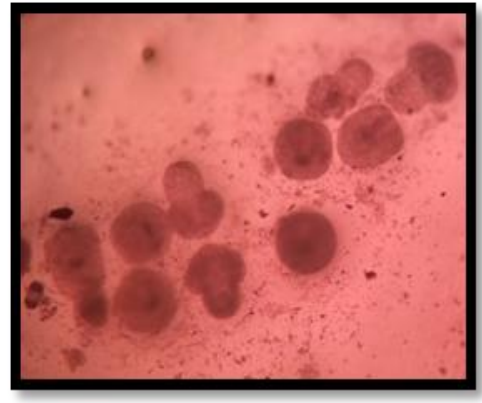

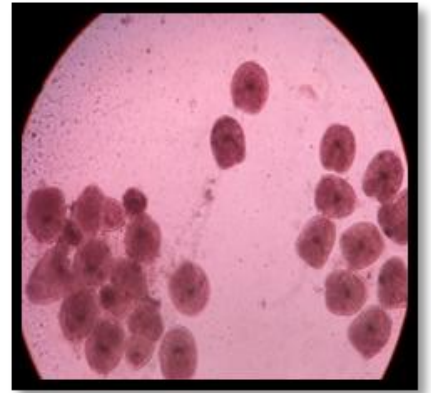

Dead protoscolices (10X)

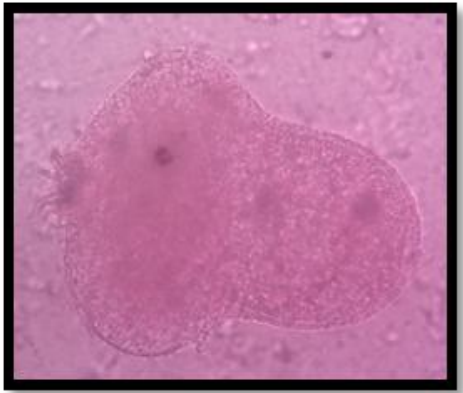

Dead protoscolices (40X)

Fig.5 Electrophoretic analysis of DNA of Echinococcus granulosus: M: 100bp DNA ladder; N1, N2, N3 and N4: Negative control; P1 and P2: Positive for Udham Singh Nagar isolates; P3 and P4: Positive for Nainital isolates

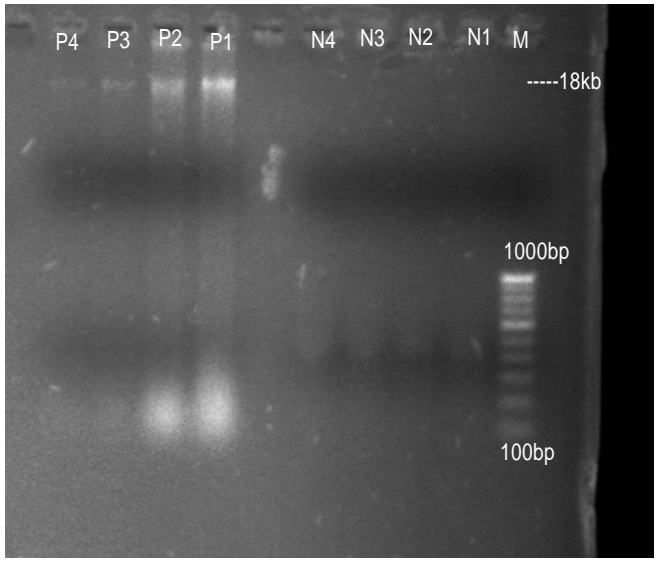

Fig.6 Electrophoretic analysis of coxl gene of Echinococcus granulosus: M: 100bp DNA ladder; P1 and P2: positive for Udham Singh Nagar isolates; P3 and P4: Positive for Nainital isolates

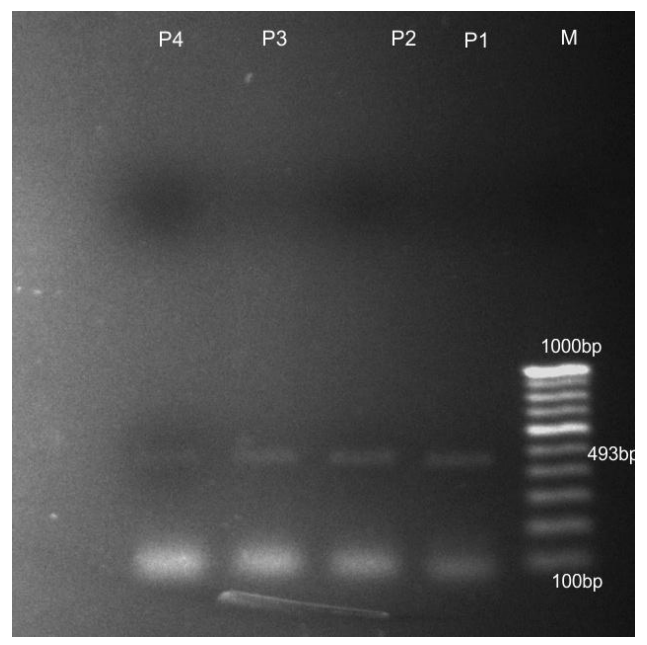


Fig.7 Phylogenetic tree based on comparison of coxl gene isolates obtained from Udham Singh nagar and Nainital districts of Uttarakhand to other genebank sequences. The lineages are shown on the tree

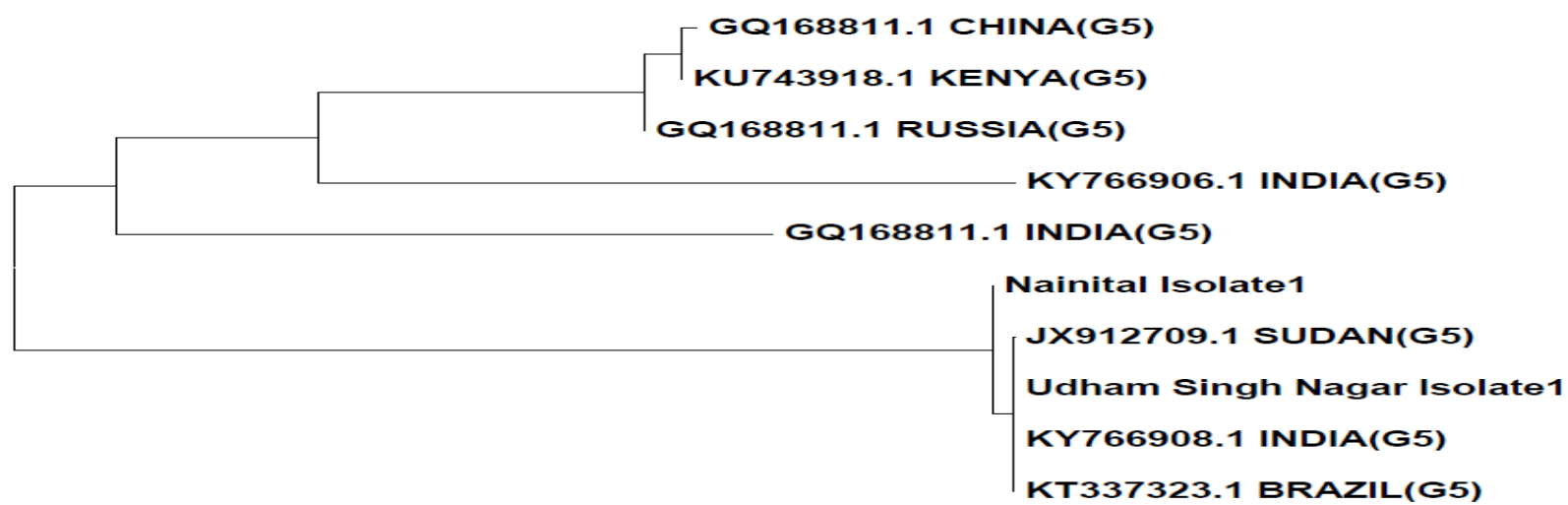

Fig.8 Percent identity and divergence between two isolates and eight published sequences of coxl gene

\begin{tabular}{|c|c|c|c|c|c|c|c|c|c|c|c|c|}
\hline & & & & & & Perce & iden & & & & & \\
\hline & 1 & 2 & 3 & 4 & 5 & 6 & 7 & 8 & 9 & 10 & & \\
\hline 1 & & 96.56 & 95.78 & 95.16 & 95.18 & 95.16 & 95.16 & 96.49 & 96.71 & 95.16 & 1 & GQ168811.1_INDIA(G5) \\
\hline 2 & 3.44 & & 97.15 & 95.32 & 95.50 & 95.32 & 95.32 & 99.96 & 99.9 & 95.32 & 2 & GQ168811.1_CHNA(G5) \\
\hline 3 & 4.22 & 2.85 & & 94.44 & 94.67 & 94.44 & 94.44 & 97.14 & 9.13 & 94.44 & 3 & KY7669066.1__NDIA(G5) \\
\hline 4 & 4.84 & 4.68 & 5.56 & & 99.99 & 100 & 100 & 95.40 & 95.56 & 100 & 4 & Udham_Singh_Nagaar_Isolate1 \\
\hline 5 & 4.82 & 4.50 & 5.33 & 0.01 & & 99.99 & 99.99 & 95.58 & 95.73 & 99.99 & 5 & Nanital_solatel \\
\hline 6 & 4.84 & 4.68 & 5.56 & 0.00 & 0.01 & & 100 & 95.40 & 95.56 & 100 & 6 & KY7669008.1_NDDA(G5) \\
\hline 7 & 4.84 & 4.68 & 5.56 & 0.00 & 0.01 & 0.00 & & 95.40 & 95.56 & 100 & 7 & JX912709.1_SUDAN(G5) \\
\hline 8 & 3.51 & 0.04 & 2.86 & 4.60 & 4.42 & 4.60 & 4.60 & & 99.93 & 95.40 & 8 & KU743918.1_KENYA(G5) \\
\hline 9 & 3.29 & 0.10 & 2.87 & 4.44 & 4.27 & 4.44 & 4.44 & 0.07 & & 95.56 & 9 & GQ168811.1_RUSSIA(G5) \\
\hline 10 & 4.84 & 4.68 & 5.56 & 0.00 & 0.01 & 0.00 & 0.00 & 4.60 & 4.44 & & 10 & KT337323.1_BRAZLL(G5) \\
\hline
\end{tabular}

Besides offals of animals from unmanaged slaughter houses is easily accessible to dogs frequenting those areas (Moon and Khemalapure, 2017). This clearly indicates the role of domestic animals in the life cycle of E. granulosus. However, such studies specifically in buffaloes in the study area are rare. This study will serve as the platform to the future scope of this disease in India in order to know the cyclic relation of $\mathrm{CE}$ between animals and humans and accordingly effective control strategies can be formulated.

\section{Acknowledgements}

The authors are highly thankful to the Department of Veterinary Public Health and Epidemiology, College of Veterinary and 
Animal Sciences and Govind Ballabh Pant University of Agriculture and Technology, Pantnagar for providing the Laboratory and Library facility and also for the ICAR funded project "Outreach Programme on Zoonosis" for financial support.

\section{References}

Arif, K., Suhani, B., Mathur, K.N., Sharma, R.L. Makhdoomi, D.M., Nazir, A., Maria, A., Din, M., 2015. Retrospective study of hydatidosis in buffaloes slaughtered in Mirha Exports Private Limited in Punjab, India. Buffalo Bull, 34: 231-240.

Ahmadi, N., Dalimi, A., 2006. Characterization of Echinococcus granulosus isolates from human, sheep and camel in Iran. Infect. Genet. Evol, 6:85-90.

Amin-Pour, A., Hosseini, S., Shayan, P, 2011. Comparative genotyping of Echinococcus granulosus infecting buffalo in Iran using coxl gene. Parasitol. Res, 108: 1229-1234.

Balbinotti, H., Santos, G. B., Badaraco, J., Arend, A. C., Graichen, D. A. S., Haag, K. L, Zaha, A., 2012. Echinococcus ortleppi (G5) and Echinococcus granulosus sensu strict (G1) loads in cattle from Southern Brazil. Vet. Parasitol, 188:255-260.

Beyhan, Y.E., Umur, S.I., 2011. Molecular characterization and prevalence of cystic echinococcosis in slaughtered water buffaloes in Turkey. Vet. Parasitol, 181:174-179.

Bhattacharya, D., Bera, A.K., Bera, B.C., Pan, D., Das, S. K., 2008. Molecular appraisal of Indian animal isolates of Echinococcus granulosus. Ind. J. Med. Res, 127: 383-387.

Bowles, J., McManus, D.P., 1993. Rapid discrimination of Echinococcus species and strains using a polymerase chain reaction-based RFLP method. Mol. Biochem. Parasito, 57:231-240.

Brunetti, E., Kern, P., Vuitton, D.A., 2010. Expert consensus for the diagnosis and treatment of cystic and alveolar echinococcosis in humans. Acta Trop, 114: 1-16.

Buishi, I.E., 2011. Epidemiology of Canine Echinococcosis in Northwest Libya, Northwest Kenya and Mid-Wales UK. Ph.D. Thesis in Parasitology, Bioscience Research Institute, School of Environment and Life Science University of Salford, Salford.

Carmena, D., Cardona, G.A., 2014. Echinococcosis in wild carnivorous species: epidemiology, genotypic diversity, and implications for veterinary public health. Vet. Parasitol, 202: 69-94.

Craig, P.S., McManus, D.P., 2007. Lightowlers, M.W., Prevention and control of cystic echinococcosis. Lancet Infect. Dis, 7:385- 394.

Cucher, M.A., Macchiaroli, N., Baldi, G., Camicia, F., Prada, L., Maldonado, L., Avila, H.G., Fox, A., Gutierrez, A., Negro, P. and Lopez, R. 2016. Cystic echinococcosis in South America: systematic review of species and genotypes of Echinococcus granulosus sensu lato in humans and natural domestic hosts. Trop. Med. Int. Hlth, 21(2): 166-175.

Dalimi, A., Motamedi, G., Hosseini, M., Mohammadian, B., Malaki, H., Ghamari, Z., Ghaffari Far, F., 2002. Echinococcosis/ hydatidosis in Western Iran. Vet. Parasitol, 105:16171.

Deplazes, P., Rinaldi, L., Alvarez Rojas, C.A., Torgerson, P.R., Harandi, M.F., Romig, T., Antolova, D., Schurer, J.M., Lahmar, S., Cringoli, G., 2017. Global distribution of alveolar and cystic echinococcosis. Adv. Parasitol, 
95:315-493.

Dinkel, A., Njoroge, E.M., Zimmermann, A., Wälz, M., Zeyhle, E., Elmahdi, I.E., Romig, T., 2004. A PCR system for detection of species and genotypes of the Echinococcus granulosuscomplex, with reference to the epidemiological situation in Eastern Africa. Int. J. Parasitol, 34: 645-653.

Eckert, J., Gemmell, M.A., Meslin, F., Pawłowski, Z.S., 2001. WHO/OIE manual on echinococcosis in humans and animals: A public health problem of global concern. World Organisation for Animal Health (Office International des Epizooties) and World Health Organisation, pp. 1250.

Elmajdoub, L.O., Elhoti, K., Haded, N., 2007. Prevalence of hydatid disease in slaughtered livestock animals from Misurata abattoirs (Libya). Journal of Union of Arab Biologists Cairo, 28:163-174.

Ghasemian, O., Hoseini, G., Soleimani, M., Mahmoudi, R. and Kaboudari, A., 2018. The prevalence study of hydatid cyst in domesticated slaughtered animals in industrial abattoirs in Iran. J. Bacteriol. Mycol, 6:96-100.

Ghourai, S.K., Sahai, B.N., 1989. Studies on the incidence of hydatid disease in ruminants. Ind. J. Anim. Hlth, 28: 3941.

Godara, R., Katoch, R., Yadav, A., 2014. Hydatidosis in goats in Jammu, India. J. Parasit. Dis, 38:73-76.

Gupta, V.K., Bist, B., Agarewal, R.D. and Gupta, P., 2011. Buffalo hydatidosis in Agra city of Uttar Pradesh. J. Vet. Parasitol, 25:88-89.

Irshadullah, M., Nizami, W.A., Maepherson, C.N.I., 1989. Observations on the suitability and importance of the domestic intermediate hosts of Echinococcus granulosus in Uttar
Pradesh, India. J. Helminthol, 63: 3944.

Ito, A., Nakao, M., Sako, Y., 2007. Echinococcosis: serological detection of patients and molecular identification of parasites. Future Microbiol, 2: 439-449.

Jithendran, K.P., 1996. Occurance of hydatidosis and various liverfluke infections in sheep and goats in Kangra valley. An Abattoir study. J. Vet. Parasitol, 10:63-67.

Jones, D. H., Book Review: Statistical Methods, George W. Snedecor and William G. Cochran 1994. Ames: Iowa State University Press. J. Educ. Stat, 19: 304-307.

Khare, P., Kala, P., Gupta, R., Chauhan, N., 2014. Isolated echinococcosis of cervical region. J. Cytol, 31:102-4.

Kumar, S., Stecher, G., Tamura, K., 2016. MEGA7: Molecular evolutionary genetics analysis version 7.0 for bigger datasets. Mol. Biol. Evol, 33:1870-1874.

Latif, A.A., Tanveer, A., Maqbool, A., Siddiqi, N., Kyaw-Tanner, M., Traub, R.J., 2010. Morphological and molecular characterisation of Echinococcus granulosus in livestock and humans in Punjab, Pakistan. Vet. Parasitol, 170:44-49.

McManus D., 2010. Echinococcosis with particular reference to Southeast Asia. Adv. Parasitol, 72: 267-303.

McManus, D., Thompson, R., 2003.Molecular epidemiology and taxonomy of cystic echinococcosis. Parasitol, 127:S37S51.

Mohamadin, S.A., Abdelgadir, A.E., 2011. Study on hydatid cyst infection in slaughter houses in Khartoum state, Sudan. Arch. Appl. Sci. Res, 3:18-23.

Moon, S.L., Khemalapure, S.S., 2017. Echinococcosis: current Indian scenario. Global J. Bio-sci. 
Biotechnol, 6:383-389.

Moro, P., Schantz, P.M. 2009. Echinococcosis: a review. Int. J. Infect. Dis., 13: 125-133.

Nadery, B. Mahdi, Y., Mohammmad, A.D., 2011. Survey on hydatid cyst infestation in Sarab city using epidemological and seroepidemological study. J. Anim. Vet. Adv, 10, 2099-2101.

Nakao, M., Lavikainen, A., Yanagida, T. and Ito, A., 2013. Phylogenetic systematics of the genus Echinococcus (Cestoda: Taeniidae). Int. J. Parasitol, 43:1017-1029.

Nakao, M., McManus, D., Schantz, P., Craig, P., Ito, A., 2007. A molecular phylogeny of the genus Echinococcus inferred from complete mitochondrial genomes. Parasitol, 134:713-722.

National Institute of Communicable Diseases (NICD), 2005. Zoonotic diseases of public health importance. Emerg. Infect. Dis, 11:1842.

Omar, M., Sultan, K., Haridy, M., Omran, A., 2013. Prevalence of cystic echinococcosis in slaughtered ruminants in different abattoirs. Am. J. Anim. Vet. Sci, 8:117-121.

Pednekar, R.P., Gatne, M.L., Thompson, R.C.A., Traub, R.J., 2009. Molecular and morphological characterisation of Echinococcus from food producing animals in India. Vet. Parasitol, 65:5865.

Petrone, L., Vanini, V., Petruccioli, E., Ettorre, G.M., Rizzi, E.B., Schinina, V., Girardi, E., Ludovisi, A., GómezMorales, M.Á., Pozio, E., Teggi, A., 2015. IL-4 specific-response in whole blood associates with human cystic echinococcosis and cyst activity. $\mathrm{J}$. Infect. Dis, 70:299-306.

Polat, P., Atamanalp, S. S., 2009. Hepatic hydatid disease: radiographics findings. The Eurasian J. Med, 41:49.
Pour, A.A., Hosseini, S.H., Shayan, P., 2012. The prevalence and fertility of hydatid cysts in buffaloes from Iran. J. Helminthol, 86, 373-377.

Raman, M., John, L., 2003. Prevalence of hydatidosis in sheep and goats in Chennai, India. Ind. J. Anim. Res, 37:57-58.

Rialch, A., Raina, O.K., Tigga, M., Anandanarayanan, A., Ganaie, Z., Aftab, A., Lalrinkima, H., Norjit, M., Varghese, A., Samanta, S., Banerjee, P.S., Singh, P., Verma, M.R., 2018. Evaluation of Echinococcus granulosus recombinant $E g \mathrm{AgB} 8 / 1$, $E g \mathrm{AgB} 8 / 2$ and EPC1 antigens in the diagnosis of cystic echinococcosis in buffaloes Vet. Parasitol, 252:29-34.

Saitou, N., Nei, M., 1987. The neighborjoining method: A new method for reconstructing phylogenetic trees. Mol. Biol. Evol, 4:406-425.

Sambrook, J., Fritsch, E.F., Maniatis, T., 1989. Molecular Cloning: A Laboratory Manual, Cold Spring Harbor Laboratory, $2^{\text {nd }}$ Edition. Cold Spring Harbor Laboratory Press, pp. $1-28$.

Samra, M.D. Deha, D.K., Borkakoty, M.R., 2000. Occurrence of hydatidosis and porcine cysticercosis in Guwahati city. J. Vet. Parasitol, 32:33-34.

Sangaran, A., Arunkumar, S., John, L., 2014. Incidence of hydatidosis in slaughtered sheep and goats. Ind. J. Vet. Anim. Sci. 43:156-158.

Shahzad, W., Abbas, A., Munir, R., Khan, M.S., Avais, M., Ahmad, J., Rana, M.Y., Mehmood, F., 2014. A PCR analysis of prevalence of Echinococcus granulosus genotype G1 in small and large ruminants in three districts of Punjab, Pakistan. Pak. J. Zool, 46, 1541-1544.

Shahi, S., Bhandari, G., Gupta, K., Kashmira, M., 2015. Pelvic hydatid disease 
mimicking ovarian cyst. J. Med. Soc, 29: 177-179.

Sharifiyazdi, H., Oryan, A., Ahmadnia, S., Valinezhad, A., 2011. Genotypic characterization of Iranian camel (Camelus dromedarius) isolates of Echinoccocus granulosus. J. Parasitol, 97:251-255.

Sharma, M., Sehga, R., Fomda, AB., Malhotra, A., Malla, N., 2013. Molecular characterization of Echinococcus granulosus cysts in north Indian patients: identification of G1, G3, G5 and G6 genotypes. PLoS Negl. Trop. Dis, 7: e2262.

Singh, B.B., Dhar, D.N., 1998. Echinococcus granulosus in animals in Northern India. J. Vet. Parasitol, 28:261- 266.

Singh, B.B., Sharma, J.K., Ghataka, S., Sharma, R., Bal, M.S., Tuli, A., Paul, J. and Gill, S. 2012. Molecular epidemiology of echinococcosis from food producing animals in North India. Vet. Parasitol, 186: 503-506.

Singh, B.B., Sharma, R., Sharma, J., Gill, J.S., 2014. Molecular detection of Echinococcus granulosus sheep strain (G1) infections in naturally infected dogs in Punjab (India). Helminthologia, 51: 269-272.

Singh, P., Keshri, A., Prakash, S., 2016. Hydatid cyst-our institutional experience in hill area of Uttarakhand. Int. J. Med. Res, 11:2024-2031.

Tamura, K., Nei, M., Kumar S., 2004. Prospects for inferring very large phylogenies by using the neighborjoining method. Proceedings of the
National Academy of Sciences 101: 11030-11035.

Tashani, O.A., Zhang, L.H., Boufana, B., Jegi, A., McManus, D.P., 2002. Epidemiology and strain characteristics of Echinococcus granulosus in the Benghazi area of Eastern Libya. Ann. Trop. Med. Parasitol, 96:369-381.

Thompson, R.C.A. and McManus, D.P. 2002. Towards a taxonomic revision of the genus Echinococcus. Trends in Parasitol, 18: 452457.

Thompson, R., 2008. The taxonomy, phylogeny and transmission of Echinococcus. Expt. Parasitol, 119:439-446.

Thompson, R.C.A., Jenkins, D.J., 2014. Echinococcus as a model system: biology and epidemiology. Int. J. Parasitol, 44:865-877.

Vural, G., Baca, A.U., Gauci, C.G., Bagci, O., Gicik, Y., Lightowlers, M.W., 2008. Variability in the Echinococcus granulosus cytochrome c oxidase 1 mitochondrial gene sequence from livestock in Turkey and a re-appraisal of the G1-3 genotype cluster. Vet. Parasito, 154:347-350.

World Health Organisation (WHO), 2017. Echinococcosis. FactSheetNo.377. World Health organization GenevaSwitzerland updated March 2017, http://www.who.int/ mediacentre/ factsheets/fs377/en/.

Zugin, J.A., Hartley, J.L., 1985 Ethanol precipitation of DNA. Focus7, 1-2.

\section{How to cite this article:}

Omer Mohi U Din Sofi, Stuti Vatsya, Rajeev Ranjan Kumar and Upadhyaya, A.K. 2019. Cystic Echinococcosis in Buffaloes from Northern Region of India: Prevalence and Molecular Characterization. Int.J.Curr.Microbiol.App.Sci. 8(05): 347-364.

doi: https://doi.org/10.20546/ijcmas.2019.805.041 